\title{
Absorption and oxidation of nitrogen oxide in ionic liquids
}

Kunov-Kruse, Andreas Jonas; Thomassen, Peter Langelund; Riisager, Anders; Mossin, Susanne; Fehrmann, Rasmus

Published in:

Chemistry - A European Journal

Link to article, DOI:

10.1002/chem.201601166

Publication date:

2016

Document Version

Peer reviewed version

Link back to DTU Orbit

Citation (APA):

Kunov-Kruse, A. J., Thomassen, P. L., Riisager, A., Mossin, S., \& Fehrmann, R. (2016). Absorption and oxidation of nitrogen oxide in ionic liquids. Chemistry - A European Journal, 22(33), 11745-11755.

https://doi.org/10.1002/chem.201601166

\section{General rights}

Copyright and moral rights for the publications made accessible in the public portal are retained by the authors and/or other copyright owners and it is a condition of accessing publications that users recognise and abide by the legal requirements associated with these rights.

- Users may download and print one copy of any publication from the public portal for the purpose of private study or research.

- You may not further distribute the material or use it for any profit-making activity or commercial gain

- You may freely distribute the URL identifying the publication in the public portal

If you believe that this document breaches copyright please contact us providing details, and we will remove access to the work immediately and investigate your claim. 


\title{
Absorption and oxidation of nitrogen oxide in ionic liquids
}

\author{
Andreas J. Kunov-Kruse ${ }^{[a]}$, Peter L. Thomassen ${ }^{[a]}$, Anders Riisager ${ }^{[a]}$, Susanne Mossin ${ }^{[a],{ }^{*}}$, Rasmus \\ Fehrmann*[a]
}

Abstract: A new strategy for capturing nitrogen oxide, NO from the gas phase is presented. Dilute NO gas is removed from the gas phase by ionic liquids at ambient conditions. The nitrate anion of the ionic liquid catalyzes the oxidation of $\mathrm{NO}$ to nitric acid $\left(\mathrm{HNO}_{3}\right)$ by atmospheric oxygen in the presence of water. The nitric acid is

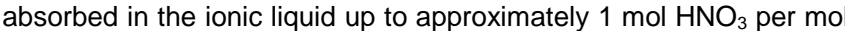
of ionic liquid due to the formation of hydrogen bonds. The nitric acid can be desorbed by heating, regenerating the ionic liquid with excellent reproducibility. Here, time resolved in-situ spectroscopic investigations of the reaction and products are presented. The procedure reveals a new vision for removing the pollutant, NO, by absorption into a non-volatile liquid and converting it into a useful bulk chemical, $\mathrm{HNO}_{3}$.

\section{Introduction}

The man made emission of $\mathrm{NO}_{x}\left(\mathrm{~N}_{2} \mathrm{O}, \mathrm{NO}, \mathrm{NO}_{2}\right)$ is of environmental concern since $\mathrm{NO}_{x}$ participates in detrimental photochemical reactions in both the troposphere and the stratosphere. ${ }^{[1]} \mathrm{NO}_{x}$ reacts with hydrocarbon containing pollutants to form health-threatening smog in densely populated areas, as well as being active in depleting the ozone layer. The end product, $\mathrm{NO}_{2}$, contributes to acid rain. To remove the $\mathrm{NO}_{x}$ from flue gasses, ammonia or hydrocarbons are generally used as reductants in the excellently performing SCR reaction. This technology is, however, not attractive for specialized applications, e.g. for $\mathrm{NO}_{x}$ removal on ships or in biomass fired and co-fired power plants, where an end-of-pipe cleaning technology is preferred.

The unique properties of ionic liquids (ILs) include high thermal stability, practically no vapor pressure and a large electrochemical window. ${ }^{[2-5]}$ Recent research has focused on the use of ILs for selective absorption of acidic gasses such as $\mathrm{CO}_{2}$ and $\mathrm{SO}_{2} \cdot{ }^{[6-9]}$ In addition a recent comprehensive review on gas solubilities in ILs concerns not only $\mathrm{CO}_{2}$ and $\mathrm{SO}_{2}$ but reports also on all other gases known to solubilize in ILs. ${ }^{[10]}$ It is remarkable that no data on NO solubilities in ILs are reported so far. $\mathrm{SO}_{2}$ capture by ILs is suggested to depend on association of $\mathrm{SO}_{2}$ with the anion of the IL. ${ }^{[7]}$ This has later been confirmed by $X$-ray investigations of crystalline $[\mathrm{TMGH}] \mathrm{Cl} \cdot \mathrm{SO}_{2}(\mathrm{TMGH}=$ 1,1,3,3-tetramethylguanidinium). ${ }^{[11]} \mathrm{CO}_{2}$ capture by ILs similarly depends on association between the $\mathrm{CO}_{2}$ molecules and the ions. ${ }^{[8]}$ The bonds formed are often relatively weak and therefore, the gas can be easily expelled from the IL in a regeneration step. Water is inevitably present in a flue gas and since water also interacts with the anion of the IL, ${ }^{[12]}$ water is a likely inhibitor in both cases. Oxygen from the flue gas may also interfere with the absorption. ${ }^{[13]}$ Here a different strategy to remove $\mathrm{NO}$ and $\mathrm{NO}_{2}$ from a gas stream is proposed, where the water and oxygen present are actively utilized to chemically convert the $\mathrm{NO}_{x}$ into nitric acid, $\mathrm{HNO}_{3}$, which then accumulates in the IL due to the formation of strong hydrogen bonds. ${ }^{[14]}$

The current work present in-situ Attenuated Total Reflectance Fourier Transform Infrared (ATR-FTIR) spectroscopic results of interaction between a thin IL film and a combined gas stream containing dilute NO gas, atmospheric air and water. From timeresolved experiments mechanistic evidence for the oxidation and absorption reactions as well as the stoichiometry of the absorption have been extracted. The accumulated $\mathrm{HNO}_{3}$ can be desorbed by heating the $\mathrm{IL}$ above $120^{\circ} \mathrm{C}$. The IL is completely regenerated with no trace of decomposition products observed.

\section{Results and Discussion}

A thin film of IL was monitored with ATR-FTIR spectroscopy during exposure to a controlled gas flow containing NO. A schematic of the setup is shown in Fig. S1 (Supporting Information). The influence of cations and anions of the IL on the reactivity was also investigated. The employed cations are depicted in Chart 1.

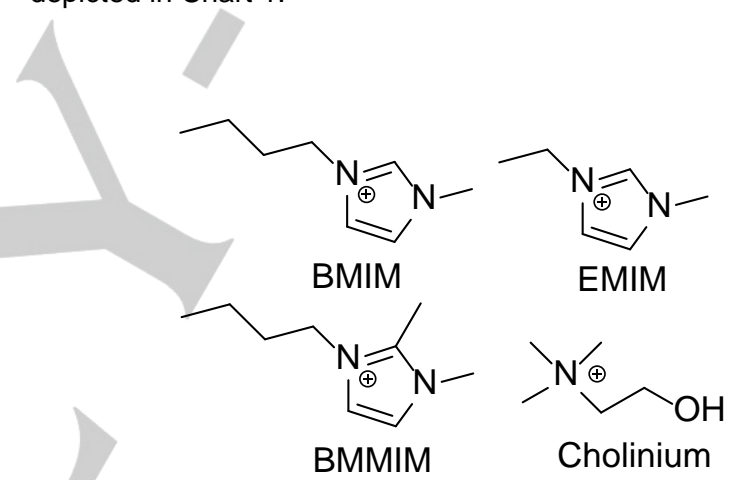

Scheme 1. IL cations used in this work. BMIM = 1-butyl-3-methylimidazolium EMIM = 1-ethyl-3-methylimidazolium, BMMIM = 1-butyl-2,3 dimethylimidazolium, cholinium $(\mathrm{Ch})=\mathrm{N}$-(2-hydroxyethyl) $\mathrm{N}, \mathrm{N}, \mathrm{N}$ trimethylammonium.

The characteristic IR bands observed and monitored during the reactions were: Nitrate $\left(\mathrm{NO}_{3}^{-}\right): 1340 \mathrm{~cm}^{-1}$ (vs); nitric acid $\left(\mathrm{HNO}_{3}\right)$ : $948 \mathrm{~cm}^{-1}(\mathrm{~s}), 1660 \mathrm{~cm}^{-1}(\mathrm{~s})$; water $\left(\mathrm{H}_{2} \mathrm{O}\right): 3400 \mathrm{~cm}^{-1}(\mathrm{~s}), 1640 \mathrm{~cm}^{-1}$ (s); dinitrogen tetroxide $\left(\mathrm{N}_{2} \mathrm{O}_{4}\right): 1858 \mathrm{~cm}^{-1}(\mathrm{w}), 1750 \mathrm{~cm}^{-1}(\mathrm{vs})$, $750 \mathrm{~cm}^{-1}(\mathrm{w})$; acetate $\left(\mathrm{CH}_{3} \mathrm{COO}^{-}\right): 1550 \mathrm{~cm}^{-1}$ (vs) and acetic acid $\left(\mathrm{CH}_{3} \mathrm{COOH}\right): 1710 \mathrm{~cm}^{-1}$ (vs). ${ }^{[15,16]}$ The bands corresponding to the IL cations do not change significantly during the experiments. ${ }^{[17]}$

According to calculation, the nitric acid band at $948 \mathrm{~cm}^{-1}$ corresponds to the symmetric O-N-O bend. The experiments are in agreement with this since the band does not shift when the water in the gas stream is exchanged with $\mathrm{D}_{2} \mathrm{O}$. The other characteristic peak for $\mathrm{HNO}_{3}$ at $1660 \mathrm{~cm}^{-1}$ shifts to $1610 \mathrm{~cm}^{-1}$ with deuterium substitution (Chart 2). 
<smiles>CO[N+](=O)OC</smiles><smiles></smiles><smiles>CO[N+](=O)[O-]</smiles>

$1420 \mathrm{~cm}^{-1}$ and $1310 \mathrm{~cm}^{-1}$<smiles>CO[N+](=O)OC</smiles><smiles>COO[N+](=O)OC</smiles>

$$
\begin{array}{ll}
\mathrm{HNO}_{3}: 940 \mathrm{~cm}^{-1} & \mathrm{HNO}_{3}: 1660 \mathrm{~cm}^{-1} \\
\mathrm{DNO}_{3}: 940 \mathrm{~cm}^{-1} & \mathrm{DNO}_{3}: 1610 \mathrm{~cm}^{-1}
\end{array}
$$

Scheme 2. Top: Assigned IR modes of $\mathrm{NO}_{3}{ }^{-}, \mathrm{HNO}_{3}$ and their complexes. Assignment based on calculated frequencies of $\mathrm{NO}_{3}, \mathrm{NO}_{3} \cdots \mathrm{HNO}_{3}$ and $\mathrm{HNO}_{3}$. The analogous modes of $\mathrm{DNO}_{3}$ were assigned by observation of the red shift of lines in the experimental spectra. Calculations were performed using the B3LYP functional and the $6-31 \mathrm{G}(\mathrm{d}, \mathrm{p})$ basis set in Gaussian. ${ }^{[18]}$

\section{In-situ ATR-FTIR experiments}

A thin film of $[\mathrm{BMIM}]\left[\mathrm{NO}_{3}\right]$ was applied to the diamond surface of the IR cell and exposed to a gas stream containing different concentrations of $\mathrm{NO}(1-6 \% \mathrm{v} / \mathrm{v})$ in combination with $\mathrm{O}_{2}(8-18 \%$ $\mathrm{v} / \mathrm{v})$, water $(\sim 1 \% \mathrm{v} / \mathrm{v})$ and balance $\mathrm{N}_{2}$ at different temperatures. When applied, the IL forms a thin film on the diamond minimizing mass transfer limitations. Thus, the experiment is envisioned as a model for the interaction between the gas phase and a supported ionic liquid phase (SILP) material. ${ }^{[19]}$

The IR spectra obtained for the $2 \% \mathrm{v} / \mathrm{V}$ NO experiments at room temperature (RT) are shown in Fig. 1. The characteristic very intense band at $\sim 1340 \mathrm{~cm}^{-1}$ of the nitrate ion immediately decreases in intensity as acidic protons become available (see Chart 2). Additionally, the nitrate band splits as less symmetric hydrogen bonded species are generated, giving bands at 1426, 1330, 1295 and $1250 \mathrm{~cm}^{-1}$, see Fig. 1. Similarly, within $20 \mathrm{sec}$ of gas exposure the characteristic peaks of the solvated $\mathrm{HNO}_{3}$ molecule at 940 and $1660 \mathrm{~cm}^{-1}$ increase in intensity. An isosbestic point is clearly observed at $1400 \mathrm{~cm}^{-1}$. Another isosbestic point at $1300 \mathrm{~cm}^{-1}$ is less well defined due to weak intensity peaks from HONO at 1260 and $1290 \mathrm{~cm}^{-1}$. The presence of isosbestic points confirm that essentially only two forms of the nitrate ion exist in the solution; free as in pure $[\mathrm{BMIM}]\left[\mathrm{NO}_{3}\right]$ and in a strong hydrogen bond with $\mathrm{HNO}_{3}$. A reference experiment was performed in order to assess whether the reaction proceeds without $\mathrm{O}_{2}$. No reaction was observed when $[\mathrm{BMIM}]\left[\mathrm{NO}_{3}\right]$ was first left to equilibrate with the atmosphere and then exposed to NO $(10 \% \mathrm{v} / \mathrm{v})$ for 80 minutes (Fig. S2). Therefore the disproportionation of $\mathrm{NO}$ and the presence of a $\mathrm{NO}_{2}$ impurity in the gas stream are both dismissed as the reason for the observed activity. A control experiment with dry $\mathrm{NO}$ and $\mathrm{O}_{2}$ on a dry IL film was also performed and we could determine that the reaction was indeed slower when water was the limiting factor. The only source for the protons in the observed $\mathrm{HNO}_{3}$ was water present either in the $\mathrm{IL}$ or in the gas phase and no other type of reactivity was observed in experiments with $\mathrm{NO}$ gas. If $\mathrm{NO}, \mathrm{O}_{2}$ and $\mathrm{H}_{2} \mathrm{O}$ are all present the characteristic $\mathrm{HNO}_{3}$ bands appear within minutes of exposure of the IL film to t. Thus it was concluded that $\mathrm{HNO}_{3}$ is only formed when all three components are present simultaneously.

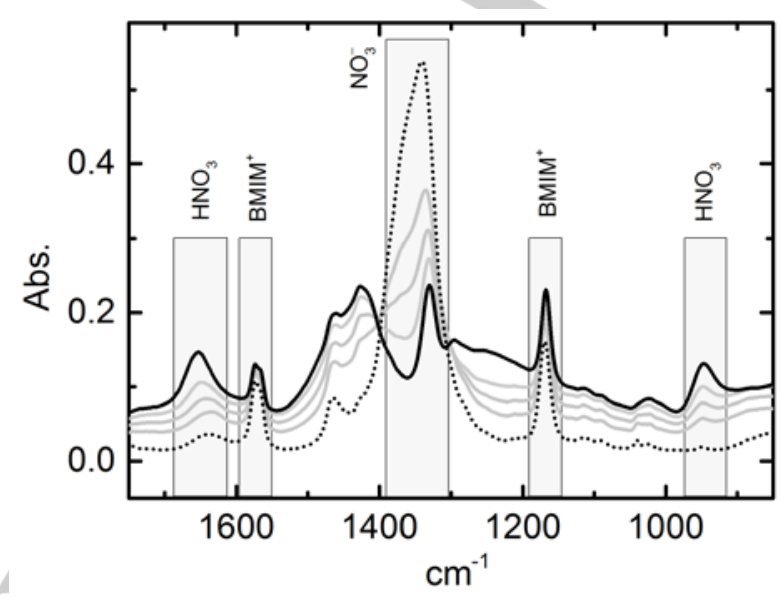

Figure 1: ATR-FTIR spectra of $\left[\mathrm{BMIM}^{-}\left[\mathrm{NO}_{3}\right]\right.$ exposed to a gas stream containing $\mathrm{NO}(2 \% \mathrm{v} / \mathrm{v}), \mathrm{O}_{2}(16 \% \mathrm{v} / \mathrm{v})$ and water $(\sim 1 \% \mathrm{v} / \mathrm{v})$ at RT. The dotted line corresponds to the spectrum of pure IL exposed to air saturated with water and the solid black line to the steady state spectrum obtained after 15 min gas exposure. Intermediate spectra are indicated with grey lines. The most intense identifiable bands are indicated.

\section{[BMIM] $\left[\mathrm{CH}_{3} \mathrm{COO}\right]$}

The experiment using [BMIM] $\left[\mathrm{CH}_{3} \mathrm{COO}\right]$ is shown in Fig. 2. Initially, a prominent water band at $3400 \mathrm{~cm}^{-1}$ (not shown) was present since $[\mathrm{BMIM}]\left[\mathrm{CH}_{3} \mathrm{COO}\right]$ is hygroscopic and has a significant content of water when in equilibrium with the atmosphere. It was eroded quickly as the reaction progressed. The prominent acetate bands at 1570 and $1380 \mathrm{~cm}^{-1}$ disappeared within a few minutes, while a band from acetic acid concurrently appeared at $1710 \mathrm{~cm}^{-1}$. After longer time of exposure, the $\mathrm{HNO}_{3}$ bands appeared and bands corresponding to both acids coexisted. After gas exposure for more than 5 minutes (or after gentle heating to $80^{\circ} \mathrm{C}$ ) the acetic acid was lost, as indicated by the disappearance of the bands assignable to both acetate and acetic acid. Hence, only the bands from nitric acid and hydrogen bonded nitrate remained. When heated to $120{ }^{\circ} \mathrm{C}$ the nitric acid bands were finally also completely lost, and the resulting spectrum features again the characteristic nitrate band at $1340 \mathrm{~cm}^{-1}$ corresponding to the spectrum of pure $[\mathrm{BMIM}]\left[\mathrm{NO}_{3}\right]$. The minor differences were assigned to the different water content of the ILs. Desorption is gradual and most of the nitric acid is desorbed before $120^{\circ} \mathrm{C}$. Interestingly, the temperature of complete desorption corresponds to the boiling temperature of the azeotrope of nitric acid and water (bp $\left.121{ }^{\circ} \mathrm{C}\right),{ }^{[20]}$ whereas pure nitric acid boils at $83^{\circ} \mathrm{C}$. On the other hand, water and acetic acid (bp $118{ }^{\circ} \mathrm{C}$ ) do not form an azeotrope and the complete loss of acetic acid was accordingly observed at significantly lower temperatures. 


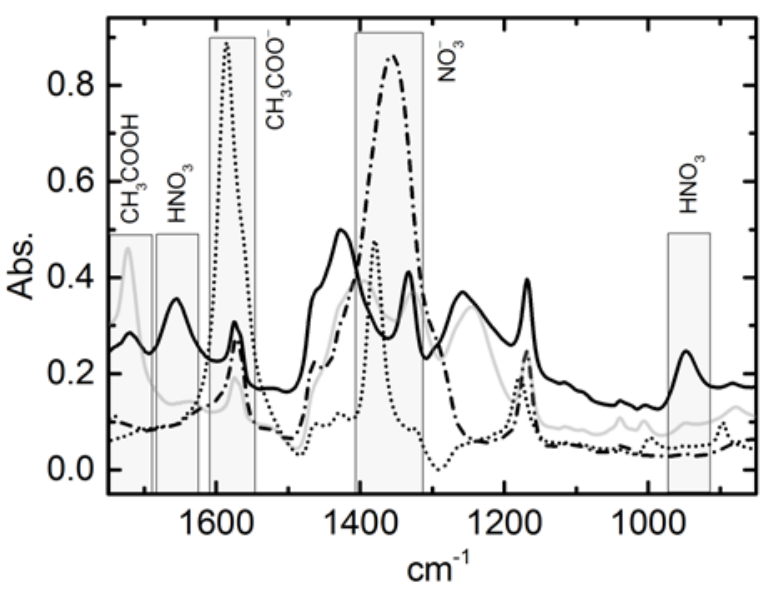

Figure 2: ATR-FTIR spectrum of [BMIM] $\left[\mathrm{CH}_{3} \mathrm{COO}\right]$ exposed to a gas stream containing $\mathrm{NO}(6 \% \mathrm{v} / \mathrm{v}), \mathrm{O}_{2}(8 \% \mathrm{v} / \mathrm{v})$ and water $(\sim 1 \% \mathrm{v} / \mathrm{v})$ at $\mathrm{RT}$. The dotted line corresponds to the spectrum of pure IL exposed to air saturated with water whereas the grey and black solid lines correspond to the spectra recorded after 7 and 12 min gas exposure, respectively. The dash-dot line corresponds to the spectrum recorded after heating to $120^{\circ} \mathrm{C}$ and subsequent cooling to RT.

\section{[BMIM]Cl}

A similar experiment for [BMIM]Cl is shown in Fig. 3. Here the bands from the cation are more readily identified. The final spectrum obtained after exposure to $\mathrm{NO}, \mathrm{O}_{2}$ and $\mathrm{H}_{2} \mathrm{O}$ was identical to the spectrum recorded in the $[\mathrm{BMIM}]\left[\mathrm{NO}_{3}\right]$ experiments. The absence of isosbestic points, however, indicates the formation of an intermediate. The strong band at $1360 \mathrm{~cm}^{-1}$ identifies the intermediate as a non-hydrogen-bonding nitrate anion (vide infra).

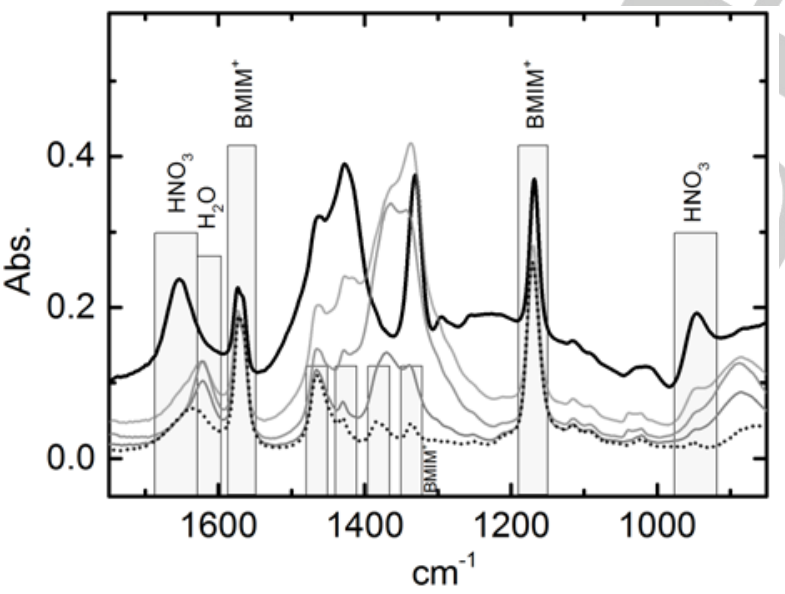

Figure 3: ATR-FTIR spectrum of [BMIM]Cl exposed to a gas stream containing $\mathrm{NO}(6 \% \mathrm{v} / \mathrm{v}), \mathrm{O}_{2}(8 \% \mathrm{v} / \mathrm{v})$ and water $(\sim 1 \% \mathrm{v} / \mathrm{v})$ at RT. The dotted line corresponds to the spectrum of pure IL exposed to air saturated with water the grey lines to the spectra recorded after 2, 3 and 4 min of gas exposure, respectively. The solid black line corresponds to the spectrum at steady state after 6 min of gas exposure.

\section{$[\mathrm{EMIM}]\left[\mathrm{CF}_{3} \mathrm{SO}_{3}\right]$}

[EMIM] $\left[\mathrm{CF}_{3} \mathrm{SO}_{3}\right]$ was investigated in the same setup (Fig. 4). The oxidation reaction forming $\mathrm{HNO}_{3}$ was observed, but at a slower rate compared to the nitrate- and chloride-based ILs.

Notably, the strong bands from nitrate were not observed after desorption, whereas the strong bands originating from the triflate anion were observed throughout the experiment. The latter bands only changed moderately after accumulation of $\mathrm{HNO}_{3}$ in the IL, suggesting that hydrogen bonding of $\mathrm{HNO}_{3}$ to the anion was present but less pronounced than observed in the experiments with the nitrate IL. Hence, the strong triflate band centered at $1270 \mathrm{~cm}^{-1}$ (asymmetric $\mathrm{S}=\mathrm{O}$ stretch) lost intensity and became broadened when $\mathrm{HNO}_{3}$ was present but regained intensity after desorption.

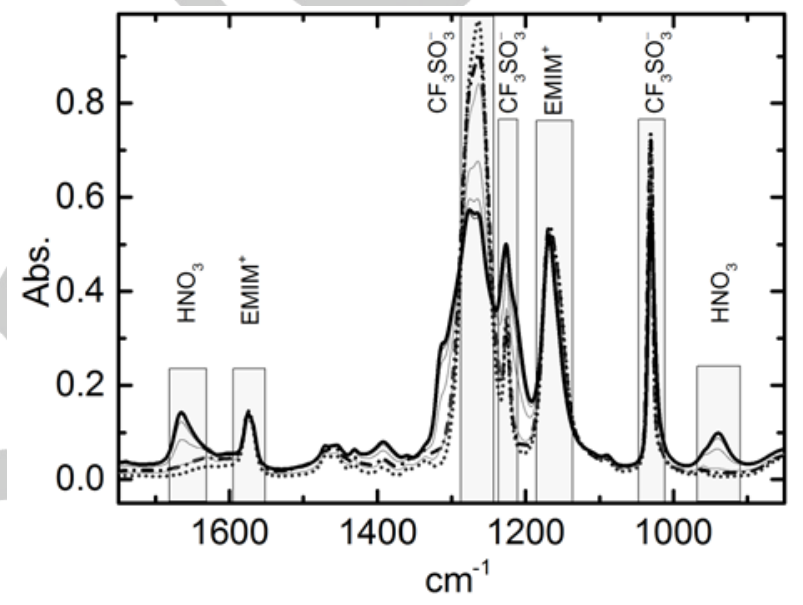

Figure 4: ATR-FTIR spectrum of [EMIM] $\left[\mathrm{CF}_{3} \mathrm{SO}_{3}\right]$ exposed to a gas stream containing $\mathrm{NO}(6 \% \mathrm{v} / \mathrm{v}), \mathrm{O}_{2}(8 \% \mathrm{v} / \mathrm{v})$ and water $(\sim 1 \% \mathrm{v} / \mathrm{v})$ at RT. The dotted line corresponds to the spectrum of the pure IL, the solid black line to the spectrum of the saturated IL at steady state $(17 \mathrm{~min})$ while the grey lines correspond to intermediate spectra. The dash-dot line corresponds to the spectrum after heating to $120^{\circ} \mathrm{C}$ and subsequent cooling to RT.

\section{[BMMIM] $\left[\mathrm{NO}_{3}\right]$}

The C2 position of the IL imidazolium ring can be deprotonated when the anion of the $\mathrm{IL}$ is a strong base, and the formed carbene have been shown to be reactive towards $\mathrm{CO}_{2}{ }^{[21]}$ In order to discard an analogous reaction path in the current study, IR experiments were also performed with [BMMIM] $\left[\mathrm{NO}_{3}\right]$ having a methyl group in the $\mathrm{C} 2$ position of the imidazolium ring. The obtained spectral results (Fig. S3, Supporting Information) were identical to the results for $[\mathrm{BMIM}]\left[\mathrm{NO}_{3}\right]$, validating that the carbene reaction path is not relevant. Hence, all experimental results suggested that the $[\mathrm{BMIM}]^{+}$cation does not partake in the reaction. The non-involvement of the cation was further confirmed in experiments performed with acetate and nitrate based ILs containing the cheap, biodegradable and non-toxic cholinium cation (Chart 1 ). The results are shown in Figures S4 and S5 (Supporting Information) and are analogous to the ones for imidazolium ILs with the same anion. 


\section{[BMIM] $\left[\mathrm{NO}_{3}\right.$ ] and $\mathrm{NO}_{2}$}

Using dry $\mathrm{NO}_{2}$ gas instead of $\mathrm{NO}$ the experiment with [BMIM] $\left[\mathrm{NO}_{3}\right.$ ] was repeated (Fig. 5). $\mathrm{NO}_{2}$ was willingly absorbed in the $\mathrm{IL}$ and dimerized in the condensed phase, giving characteristic peaks from $\mathrm{N}_{2} \mathrm{O}_{4}$ at 1858(w), 1750(vs) and 750 (w) $\mathrm{cm}^{-1}$. ${ }^{[22]}$ Bands from $\mathrm{HONO}$ and $\mathrm{HNO}_{3}$ were also prominent after absorption, indicating disproportionation of $\mathrm{N}_{2} \mathrm{O}_{4}$ in the presence of water in the IL. When the gas feed was changed to dinitrogen saturated with water, the bands specific for $\mathrm{N}_{2} \mathrm{O}_{4}$ decreased immediately and the characteristic $\mathrm{HNO}_{3}$ bands increased.

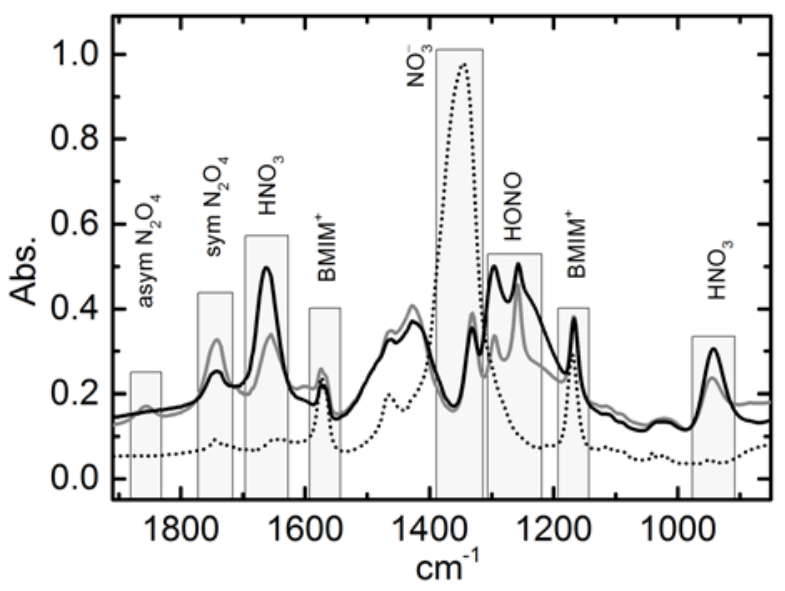

Figure 5: ATR-FTIR spectrum of $[\mathrm{BMIM}]\left[\mathrm{NO}_{3}\right]$ exposed to a gas stream containing $\mathrm{NO}_{2}$ at RT. The dotted line corresponds to the spectrum of pure IL exposed to air saturated with water, the grey line to the spectra recorded after $\mathrm{NO}_{2}$ exposure for $3 \mathrm{~min}$ and the solid black line to the spectrum recorded after subsequent $30 \mathrm{sec}$ of exposure to $\mathrm{N}_{2}$ saturated with water.

\section{Quantification of $\mathrm{HNO}_{3}$}

A standard curve for determination of the $\mathrm{HNO}_{3}$ concentration in the IL was generated by measuring IR spectra of solutions prepared by dissolving known amounts of concentrated nitric acid in $[\mathrm{BMIM}]\left[\mathrm{NO}_{3}\right]$ at RT (Fig. S6, Supporting information). Either of the $\mathrm{HNO}_{3}$ bands at 1660 and $948 \mathrm{~cm}^{-1}$ can be used to quantify the amount of $\mathrm{HNO}_{3}$ present in the IL, but since a water band overlaps with the former band the results obtained using the latter were more reliable and reproducible. Importantly, all conclusions are equally valid from quantification of the $1660 \mathrm{~cm}^{-1}$ band. The IR spectrum in the vicinity of the characteristic $\mathrm{HNO}_{3}$ vibrations at $948 \mathrm{~cm}^{-1}$ were deconvoluted by Gaussian functions, using the method described previously. ${ }^{[23]}$ The area under the Gaussian function fitted to the $948 \mathrm{~cm}^{-1}$ band in the experimental spectrum can be correlated to the $\mathrm{HNO}_{3}$ content by use of the standard curve. The uncertainty of the total $\mathrm{HNO}_{3}$ content determined by this method is estimated to be $10-20 \%$ based on the quality of the reference spectra and the fitting procedure.

The fitting procedure was applied to all time-resolved spectra at $\mathrm{RT}$ of $[\mathrm{BMIM}]\left[\mathrm{NO}_{3}\right]$, [EMIM][CF $\left.\mathrm{CO}_{3}\right],[\mathrm{BMIM}] \mathrm{Cl},[\mathrm{Ch}]\left[\mathrm{CH}_{3} \mathrm{COO}\right]$ as well as $[\mathrm{BMMIM}]\left[\mathrm{NO}_{3}\right]$ when exposed to $\mathrm{NO}(6 \% \mathrm{v} / \mathrm{v})$ with $\mathrm{O}_{2}$ and water in excess. The results are shown in Fig. 6. For the cholinium based ILs, IR bands from the cation are overlapping with the quantifiable $\mathrm{HNO}_{3}$ bands. By careful use of the peak deconvolution method reliable data were obtained. The steady state saturation point approximately corresponds to a molar ratio of 1.1:1 $\left(\mathrm{HNO}_{3}: \mathrm{IL}\right)$ for the acetate, chloride and nitrate ILs, respectively, whereas the triflate $\mathrm{IL}$ converges at a ratio of approximately 0.6. The apparent difference in absorption rate observed between $[\mathrm{BMIM}]\left[\mathrm{NO}_{3}\right]$ and $[\mathrm{BMMIM}]\left[\mathrm{NO}_{3}\right]$ was due to a difference in the absorption setup and is not considered to be significant. The time resolved spectra of $[\mathrm{BMIM}]\left[\mathrm{NO}_{3}\right]$ were measured with an improved setup allowing the IL to be exposed to the $\mathrm{NO} / \mathrm{O}_{2} / \mathrm{H}_{2} \mathrm{O}$ mixture exactly at $t=0$, whereas the switch for the other ILs was dependent on replacement of a non-negligible volume of gas before the ATR cell resulting in a concentration gradient during the first minutes of the experiment. Accordingly, the time line has been shifted $20 \mathrm{sec}$ to partially correct for this. All experiments performed under identical conditions support the conclusion that the cation does not influence the rate of absorption or the obtained molar ratio of $\mathrm{HNO}_{3}$ to IL.

The IL anion, on the other hand, is decisive for the evolution of the spectra. The acetate IL shows conversion of $\mathrm{NO}$ to $\mathrm{HNO}_{3}$ as fast as the nitrate IL, whereas the triflate IL shows a slower conversion. The slow rate of accumulation of $\mathrm{HNO}_{3}$ in [BMIM] $\left[\mathrm{CF}_{3} \mathrm{SO}_{3}\right]$ is assigned to triflate being less nucleophilic towards activation of NO. Evaluation of the IR spectra of the IL suggests that $\mathrm{HNO}_{3}$ forms hydrogen bonds to other $\mathrm{HNO}_{3}$ molecules, weak hydrogen bonds to the oxygen atoms in the triflate anion, and none to the fluorine atoms which are very poor hydrogen bond acceptors. Triflate is the anion of a stronger acid than $\mathrm{HNO}_{3}$ and is not protonated during the reaction.

Notably, the chloride IL has a significantly different overall profile with an initial induction period followed by first a slow and then a fast $\mathrm{HNO}_{3}$ formation rate, before converging to almost the same molar $\mathrm{HNO}_{3} / \mathrm{LL}$ ratio as the nitrate ILs. The difference is assigned to chloride being a stronger base than nitrate in ILs, ${ }^{[24]}$ making strong bonds to protons. The water content of $[\mathrm{BMIM}] \mathrm{Cl}$ in equilibrium with the atmosphere was determined by Karl-Fischer titration to be $5 \% \mathrm{w} / \mathrm{w}$, which corresponds to a molar ratio of about 1:2 for $\mathrm{H}_{2} \mathrm{O}$ to $\mathrm{Cl}^{-}$. This is much higher than for any of the other ILs used $\left(\sim 1 \% \mathrm{w} / \mathrm{w} \mathrm{H}_{2} \mathrm{O}\right.$ for $\left.[\mathrm{BMIM}]\left[\mathrm{NO}_{3}\right]\right)$.

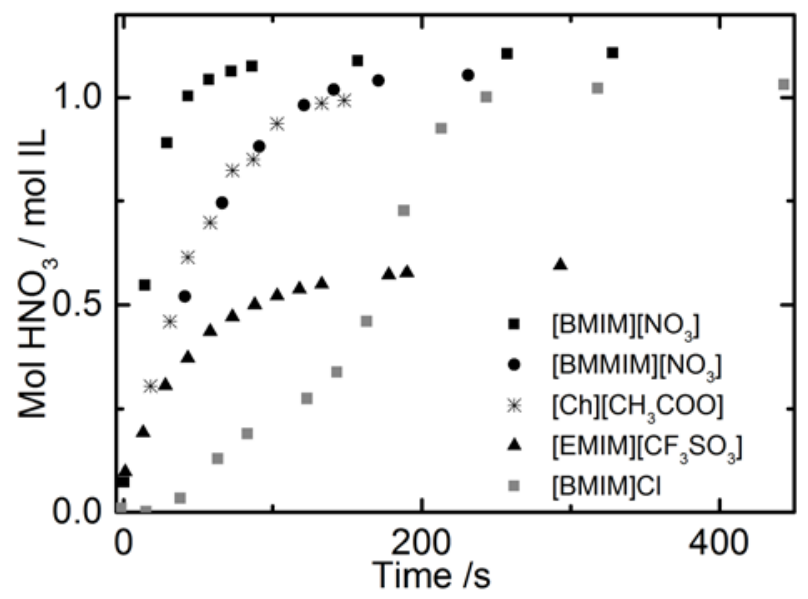

Figure 6: Integrated area of the $948 \mathrm{~cm}^{-1} \mathrm{HNO}_{3}$ band as function of exposure time to a gas stream containing $\mathrm{NO}(6 \% \mathrm{v} / \mathrm{v}), \mathrm{O}_{2}(8 \% \mathrm{v} / \mathrm{v})$ and water $(\sim 1 \%$ $\mathrm{v} / \mathrm{v}$ ) at RT. The area is converted to mole ratios using the standard curve given in Fig. S6 (Supporting Information). The experiment with $[\mathrm{BMIM}]\left[\mathrm{NO}_{3}\right]$ was 
performed with the gas above the IL changing immediately to the target composition. All the other experiments were performed with a more gradual change of the gas flow.

After the first minutes of gas exposure some water was likely driven out of the liquid and the reaction also consumed water resulting in the $3400 \mathrm{~cm}^{-1}$ water band decreasing fast. All protons generated in the reaction became bound to chloride leaving no protons to generate $\mathrm{HNO}_{3}$. Accordingly, a relatively narrow band corresponding to non-hydrogen bonded nitrate appears in Fig. 3 in the time interval corresponding to 50-150 sec in Fig. 6 and the apparent rate of generation of $\mathrm{HNO}_{3}$ is lower. After $150 \mathrm{sec}$ the rate of $\mathrm{HNO}_{3}$ formation in [BMIM]Cl increases sharply to the same value as for [BMIM] $\left[\mathrm{CH}_{3} \mathrm{COO}\right]$, $[\mathrm{BMIM}]\left[\mathrm{NO}_{3}\right],[\mathrm{Ch}]\left[\mathrm{NO}_{3}\right]$ and $[\mathrm{BMMIM}]\left[\mathrm{NO}_{3}\right]$ and the band of the non-hydrogen bonded nitrate disappears.
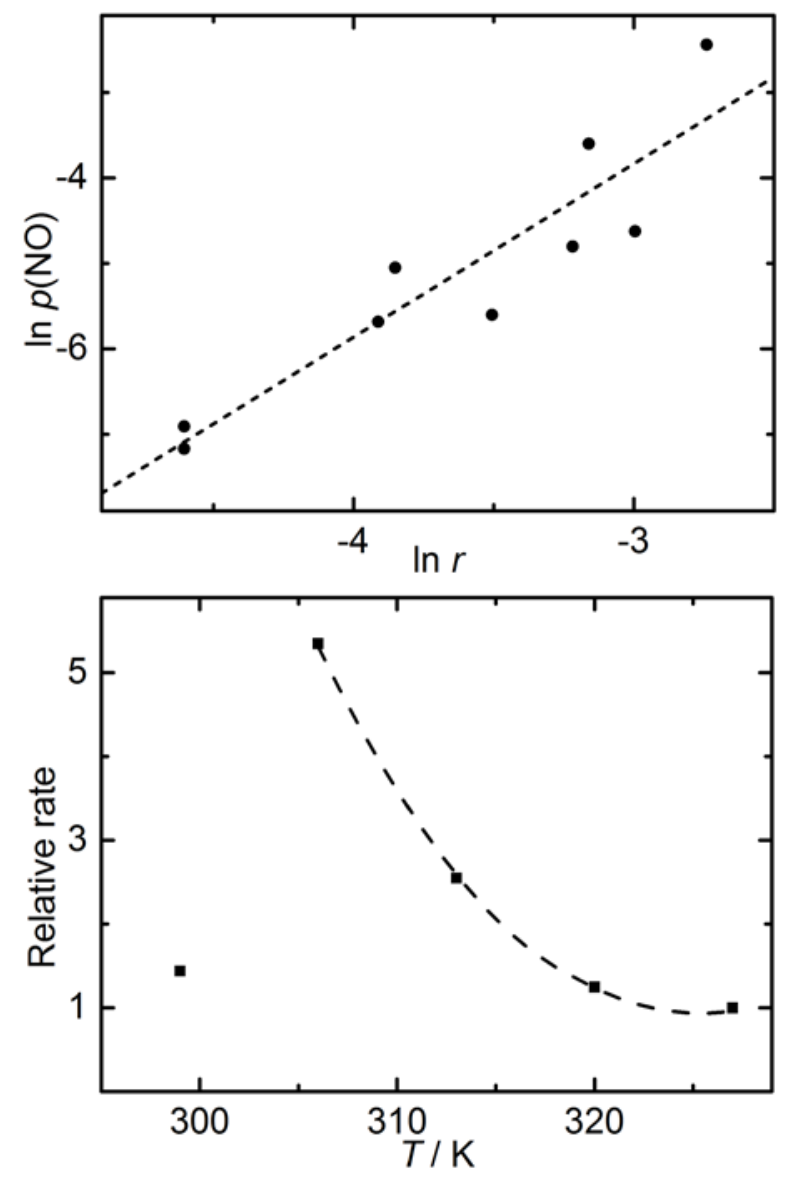

Figure 7: Top: Double logarithmic plot of maximal linear rates of $\mathrm{HNO}_{3}$ formation $(r)$ in [BMIM] $\left[\mathrm{NO}_{3}\right]$ at RT with excess water and oxygen as function of partial pressure of $\mathrm{NO}$ in the gas phase determined from the $948 \mathrm{~cm}^{-1}$ band in the in-situ ATR-FTIR spectra. The line is a fit to the data. Bottom: Relative rate of $\mathrm{HNO}_{3}$ formation in $[\mathrm{BMIM}]\left[\mathrm{NO}_{3}\right]$ with $2 \% \mathrm{v} / \mathrm{v}$ NO with excess water and oxygen at different temperatures. The line is added as a guide to the eye only.
The rate of accumulation of nitric acid in the IL is very dependent on the NO concentration as well as the temperature. [BMIM] $\left[\mathrm{NO}_{3}\right]$ was saturated with $\mathrm{HNO}_{3}$ at room temperature after $50 \mathrm{sec}$ when exposed to $6 \% \mathrm{v} / \mathrm{v} \mathrm{NO}$, excess $\mathrm{O}_{2}$ and water. With $1 \% \mathrm{v} / \mathrm{v} \mathrm{NO}$ it took $3000 \mathrm{sec}$. In the in-situ ATR-IR experiments the maximal linear rate of increase in intensity of the $\mathrm{HNO}_{3}$ band was determined. The experiment was performed multiple times with different NO concentrations at RT and the measured rates are plotted in Fig. 7, top. From these experiments an apparent order of the reaction with respect to NO was determined to be $2.0( \pm 0.3)$.

Once the $\mathrm{IL}$ is saturated with $\mathrm{HNO}_{3}$ the reaction cannot be followed further with IR performed on the IL film, but the reaction between $\mathrm{NO}$ and $\mathrm{HNO}_{3}$ is likely to continue although at a significantly lower rate. The IL provides a sticky surface where $\mathrm{NO}$ from the gas phase can react with $\mathrm{HNO}_{3}$ giving $\mathrm{NO}_{2}$ and $\mathrm{HNO}_{2}$, which are liberated to the gas stream if the IL is locally saturated. However, the liberated species might be absorbed further downstream.

The absorption of NO by the ILs is very temperature dependent giving rise to a decrease in the absorption capacities with increasing temperature (Fig. 7, bottom). The solubility of gasses in ILs generally decrease with increasing temperature. ${ }^{[25]} \mathrm{We}$ expect the same to be the case for $\mathrm{NO}, \mathrm{NO}_{2}$ and $\mathrm{O}_{2}$. On the other hand, the rate of $\mathrm{NO}$ oxidation is expected to increase with temperature. Due to the two competing effects it was not possible to generate an Arrhenius plot for the total reaction based on the experiments described here. The overall maximum rate was observed around $30{ }^{\circ} \mathrm{C}$. We assume that the rate of the NO oxidation reaction is limiting the overall rate below this temperature, and that the solubility of the reactants in the IL determines the overall rate above this temperature.

\section{Bulk experiments}

\section{Absorption followed gravimetric}

Absorption of $\mathrm{NO}$ in $[\mathrm{BMIM}]\left[\mathrm{CH}_{3} \mathrm{COO}\right]$ and $[\mathrm{BMIM}]\left[\mathrm{NO}_{3}\right]$ was performed by passing the gas slowly through bulk ILs $(\sim 1 \mathrm{~g})$ in two types of experiments. The gas uptake was followed gravimetrically. Series 1 was performed with $10 \%$ v/v NO in $\mathrm{N}_{2}$ bubbling through [BMIM] $\left[\mathrm{CH}_{3} \mathrm{COO}\right.$ ] at $100{ }^{\circ} \mathrm{C}$ for about 10 days to obtain steady state. The resulting solution was allowed to cool to RT under continuous gas exposure. $t=0$ was chosen as the point when the solution was at RT. The solution was left with time to equilibrate. After several days a new steady state had been reached (Fig. 8). Oxygen and water was not deliberately added in this experiment, since it was originally intended as a pure NO absorption experiment. Series 2 is a reproduction of series 1 with a different batch of IL. In series 3, pre-dried $[\mathrm{BMIM}]\left[\mathrm{NO}_{3}\right]$ was bubbled through with a gas stream of $5 \% \mathrm{v} / \mathrm{v}$ NO containing water and oxygen in excess (1 \% v/v and $10 \%$ $\mathrm{v} / \mathrm{v}$, respectively). The weight was followed closely until steady state. Despite the difference in conditions for series 1 and 2 compared to series 3 an identical weight increase compared to time $t=0$ was found at steady state. 
The observations are explained in the following way: In the initial stages of series 1 and 2 some water is present in the [BMIM] $\left[\mathrm{CH}_{3} \mathrm{COO}\right]$ and the precautions to keep out oxygen and water over an extended period were not sufficient. Thus NO is being oxidized to $\mathrm{HNO}_{3}$, which is a stronger acid than acetic acid and $[\mathrm{BMIM}]\left[\mathrm{CH}_{3} \mathrm{COO}\right]+\mathrm{HNO}_{3}$ will give $[\mathrm{BMIM}]\left[\mathrm{NO}_{3}\right]+$ $\mathrm{CH}_{3} \mathrm{COOH}$. The generated acetic acid is not retained in the liquid at $100{ }^{\circ} \mathrm{C}$ and is lost to the gas phase with time. At steady state the conversion is complete. This is in correspondence with the observation of the viscosity of the IL changing drastically since $[\mathrm{BMIM}]\left[\mathrm{NO}_{3}\right]$ has a much lower viscosity than [BMIM] $\left[\mathrm{CH}_{3} \mathrm{COO}\right]$ due to a weaker hydrogen bonding pattern between cation and anion. ${ }^{20,21}$ After the temperature is lowered to RT the starting point in series 1,2 , and 3 are now analogous. Series 3 reaches steady state faster since the access to oxygen and water is not limited by diffusion through tubing or presence as impurity in the gasses or setup. The end point after waiting to steady state is the same for series 1,2 and 3 . Thus we conclude that the reactivity observed for series 1 and 2 is the same as for series 3 despite the initial difference in IL and reaction conditions.

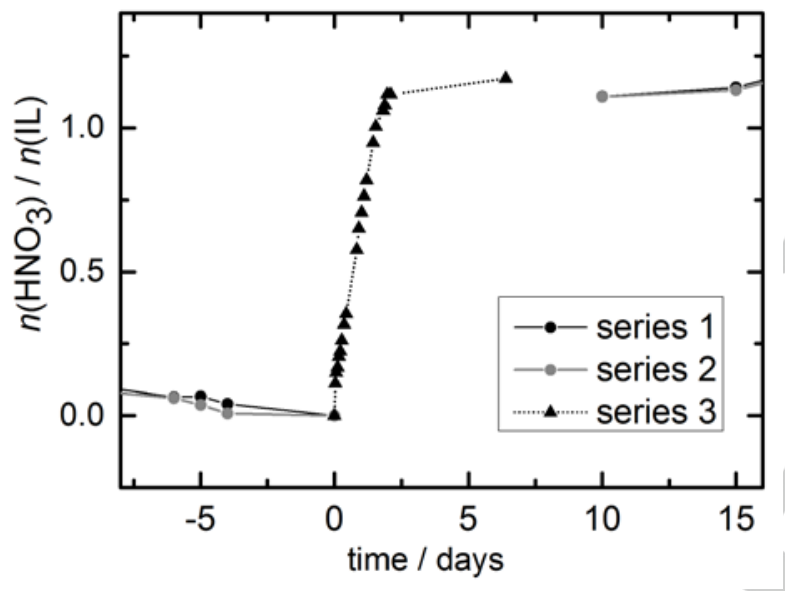

Figure 8: Increase in mass of bulk ILs as a function of time by passing a gas through the IL via a sintered glass frit at RT. The gain of mass is assumed to be due to $\mathrm{HNO}_{3}$ only and has been recalculated to a mole fraction of $\mathrm{HNO}_{3}$ relative to the IL. In series 1 and 2 [BMIM] $\left[\mathrm{CH}_{3} \mathrm{COO}\right.$ ] was exposed to a gas flow of $10 \% \mathrm{v} / \mathrm{v} \mathrm{NO}$ in $\mathrm{N}_{2}$ at $100^{\circ} \mathrm{C}$ for several days before cooling to RT (at $t=$ 0 ) under continued gas flow. In series 3, pre-dried [BMIM] $\left[\mathrm{NO}_{3}\right]$ was exposed to a gas mixture of $5 \% \mathrm{v} / \mathrm{v} \mathrm{NO}$ with excess $\mathrm{O}_{2}$ and water at RT.

\section{TGA}

Thermogravimetric analysis (TGA) performed on the pure [BMIM] $\left[\mathrm{CH}_{3} \mathrm{COO}\right.$ compared to the product after steady state confirms the transformation of the IL (see Fig. S7, Supporting Information). [BMIM] $\left[\mathrm{NO}_{3}\right]$ decomposes at temperatures well above $240{ }^{\circ} \mathrm{C}$, which is $60{ }^{\circ} \mathrm{C}$ higher than the decomposition temperature of [BMIM] $\left[\mathrm{CH}_{3} \mathrm{COO}\right]$.

\section{NMR}

${ }^{1} \mathrm{H}$ and ${ }^{13} \mathrm{C}$ NMR analyses (in $\mathrm{CDCl}_{3}$ and DMSO- $\mathrm{d}_{6}$ ) were performed on the bulk [BMIM] $\left[\mathrm{CH}_{3} \mathrm{COO}\right]$ sample after absorption to steady state with $\mathrm{NO}$ at room temperature and subsequent desorption for $3 \mathrm{~h}$ at $100-110^{\circ} \mathrm{C}$ (without gas flow). The data were compared to the NMR spectra of pure $[\mathrm{BMIM}]\left[\mathrm{NO}_{3}\right]$ (Figs. S8 and S9, Supporting Information) and were found to be almost identical. The spectra revealed no indication of proton or carbon signals attributed to acetic acid (these would be found at $\delta\left({ }^{1} \mathrm{H}\right) / \mathrm{ppm}=2.1(3 \mathrm{H}), 11.4(1 \mathrm{H}) ; \delta\left({ }^{13} \mathrm{C}\right) / \mathrm{ppm}=20.8\left(\mathrm{CH}_{3}\right), 178.1$ $(\mathrm{COOH}))$ in the sample after desorption. On the other hand, some well-defined signals at $\delta\left({ }^{1} \mathrm{H}\right) / \mathrm{ppm}\left(\mathrm{CDCl}_{3}\right)=13.8$ and $\delta\left({ }^{1} \mathrm{H}\right) / \mathrm{ppm}\left(\mathrm{DMSO}-\mathrm{d}_{6}\right)=5-6$ (broad) were observed indicating that desorption of $\mathrm{HNO}_{3}$ was not complete. No decomposition products were observed in the NMR spectra after this absorption-desorption cycle, and the chemical shifts of the imidazolium cation signals remained essentially unchanged compared to the pure $[\mathrm{BMIM}]\left[\mathrm{NO}_{3}\right]$, except for a slight upfield shift $(0.05-0.20 \mathrm{ppm})$ of the aromatic protons caused by the acidic environment.

\section{Comparison between IL and aqueous nitrate solution}

It is relevant to compare the reaction rates of uptake and oxidation of NO in IL media to the one in an analogous aqueous nitrate solution in order to prove that the IL is in fact enhancing the reaction rate and not just providing a non-volatile reaction medium. Unfortunately it is not possible to design a comparable experiment using neither the in-situ FTIR setup nor the gravimetric analysis of absorption in bulk sample. The water in the aqueous nitrate solution will evaporate fast leaving just the nitrate salt on the IR diamond and, in the bulk experiment, evaporation of water will change the weight of the solution. Instead the reactions were compared by quantifying the developed acidic protons by volumetric analysis as follows. In series 4 , a solution of $\mathrm{NaNO}_{3}$ in water having the same molar concentration of nitrate as $[\mathrm{BMIM}]\left[\mathrm{NO}_{3}\right]$ (approx. $6 \mathrm{M}$ ) was prepared. NO $(5 \% \mathrm{v} / \mathrm{v})$ and air saturated with water was bubbled through $3.0 \mathrm{~mL}$ of the solution at $10 \mathrm{~mL} / \mathrm{min}$ in a series of experiments. After 2, 4, 6, 8 and 10 hours, respectively, the gas flow was stopped and the solution was diluted with degassed water. Thymol blue was added as acid/base indicator and titration was performed with a $0.10 \mathrm{M} \mathrm{NaOH}$ solution. In series 5 the same experiments were performed on [BMIM] $\left[\mathrm{NO}_{3}\right]$. Both series 4 and 5 showed an increasing amount of acidic protons being accumulated in the liquids, as a function of the exposure time. The higher viscosity of the IL should result in hindered mass transfer across the gas/liquid interface compared to an aqueous $\mathrm{NaNO}_{3}$ solution. Despite this effect favoring the conversion in the aqueous solution it was observed that the IL had accumulated approximately 3 times as many acidic protons as the aqueous nitrate solution during the first couple of hours (see Figure S10, Supporting Information). After longer experiments, the IL approaches saturation and reacts slower whereas the aqueous solution continues to have a linear increase. Water evaporating from the aqueous solution during the experiment was partially avoided using a low flow rate and the air in the flow being saturated with water. Nevertheless some water loss could not be avoided judged by the weight change of the solution. The aqueous solution produces some precipitate of $\mathrm{NaNO}_{3}$ with time since the solubility is exceeded locally. This is not a problem for the IL where no precipitates are observed. The 
use of a frit section at the end of the gas tube inserted in the aqueous solution provided irreproducible results as sodium nitrate precipitates in the frit. Therefore an open-end $(\varnothing 1 \mathrm{~mm})$ glass tube was used for both experiments.

\section{Comparison between inert gas, $\mathrm{NO}, \mathrm{CO}_{2}$ and $\mathrm{SO}_{2}$}

In a realistic flue gas $\mathrm{CO}_{2}$ and $\mathrm{SO}_{2}$ are also present and can interact with the ionic liquid. In order to separately assess the interactions of these gasses with the ionic liquid the following control experiments were performed: 5 different gas mixtures was bubbled through $\sim 1 \mathrm{~g}$ of initially dry [BMIM] $\left[\mathrm{NO}_{3}\right]$ at 40 $\mathrm{mL} / \mathrm{min}$. See Table 1 and Figure S11.

Table 1: Absorbtion of gasses in $[\mathrm{BMIM}]\left[\mathrm{NO}_{3}\right]$ determined gravimetric and by titration with $\mathrm{NaOH}(\mathrm{aq})$.

\begin{tabular}{llllll} 
Experiment no.: & 1 & 2 & 3 & 4 & 5 \\
\hline $\mathrm{CO}_{2}$ & - & $50 \%$ & - & - & - \\
$\mathrm{SO}_{2}$ & - & - & $1 \%$ & - & - \\
$\mathrm{NO}$ & - & - & - & $5 \%$ & $0.1 \%$ \\
$\mathrm{O}_{2}$ & $10 \%$ & $10 \%$ & $10 \%$ & $10 \%$ & $10 \%$ \\
$\mathrm{H}_{2} \mathrm{O}$ & $1.4 \%$ & $1.4 \%$ & $1.4 \%$ & $1.4 \%$ & $1.4 \%$ \\
\hline After absorption for & $24 \mathrm{~h}$ & $24 \mathrm{~h}$ & $24 \mathrm{~h}$ & $8 \mathrm{~h}$ & $36 \mathrm{~h}$ \\
\hline weight increase: & & & & & \\
wt $/ \mathrm{wt} \mathrm{IL}$ & 0.10 & 0.11 & 0.09 & 0.53 & 0.11 \\
$\mathrm{~mol} \mathrm{H}^{+} / \mathrm{mol} \mathrm{IL}$ & 0 & 0 & 0.004 & 1.10 & 0.10 \\
\hline
\end{tabular}

In the first three experiments the weight increase is only water since acid-base titration reveals that the amount of acidic protons in the solutions after absorption is close to 0 . For experiment 4 with $5 \% \mathrm{NO}$ the IL is almost saturated after $6 \mathrm{~h}$ and the increase in both weight and acidity of the solution is very high. For experiment 5 with 1000 ppm NO the results show that the reaction does take place but the saturation is slow due to the low concentration of NO. The weight increase is not significantly higher than for 1-3 but acidic protons corresponding to $10 \%$ of the molar amount of IL was found after $36 \mathrm{~h}$. This corresponds to $\sim 15 \%$ of the NO in the total gas volume that was bubbled through $1 \mathrm{~g}$ of IL for $36 \mathrm{~h}$.

\section{Discussion}

The cations of the ILs do not decompose even when heated to $120^{\circ} \mathrm{C}$ in concentrated nitric acid; the original IR spectra of the nitrate and triflate ILs are completely recovered after cooling to RT even after many cycles. If bulk [BMIM] $\left[\mathrm{NO}_{3}\right]$ saturated with $\mathrm{HNO}_{3}$ is kept completely dry and heated to above $120^{\circ} \mathrm{C}$ for longer periods some yellow coloration is observed, but no irreversible decomposition products have been observed. When exposing $[\mathrm{BMIM}] \mathrm{Cl}$ to $\mathrm{NO}$, species corresponding to both hydrochloric acid and nitric acid are present in the solution, but the IL does not decompose despite being saturated with this very potent oxidation mixture. These observations show that the ILs have excellent chemical stability towards $\mathrm{H}_{x} \mathrm{~N}_{y} \mathrm{O}_{z}$ species. This is rationalized with the imidazolium ring being well protected from electrophilic attack by $\mathrm{NO}_{2}{ }^{+}$or similar species due to its positive charge. As seen from the proposed reaction pathway below, radicals originating from dioxygen are not believed to be part of the turnover of the reaction. The fact that the organic cations are unaffected by the harsh treatment is also a strong indication that the formation of uncontrollable reactive radical species is controlled in the IL media by the more stable radicals $\mathrm{NO}$ and $\mathrm{NO}_{2}$. Unprotected organic molecules or other impurities present in the IL are likely less protected and therefore oxidized and decomposed completely to $\mathrm{CO}_{2}$ and water giving a self-cleaning process of the IL during heating to the regeneration temperature.

$\mathrm{NO}_{2}$ is always present to some extent in pressurized $\mathrm{NO}$ gas bottles due to the slow, but irreversible disproportion reaction of $\mathrm{NO}$ to form $\mathrm{N}_{2} \mathrm{O}$ and $\mathrm{NO}_{2}{ }^{[26]}$ However, since no $\mathrm{HNO}_{3}$ formation was observed in absence of dioxygen in the feed gas (Fig. S2, Supporting Information), the disproportion reaction cannot account for the observed generation of $\mathrm{HNO}_{3}$. Similarly, the level of autoxidation of $\mathrm{NO}$ by dioxygen in the gas phase before contact with the IL was monitored with gas-phase UV-Vis and found to be very low and thus not responsible for the observed reactivity. Furthermore, preliminary ${ }^{[27]}$ and ongoing investigations of the gas conversion reaction with supported ionic liquid phase (SILP) absorbers reveal a much higher conversion dynamics over the IL phase compared to bypass experiments. So far several absorption (at RT) - desorption (at $130{ }^{\circ} \mathrm{C}$ ) cycles performed by SILP absorbers revealed completely reversible and unchanged capacity of the absorber.

\section{Proposed reaction cycle}

The overall reaction (1) is thermodynamically favored with $\Delta_{\mathrm{r}} G=$ $-210 \mathrm{~kJ} \mathrm{~mol}^{-1}$, but it is very slow at ambient conditions.

$4 \mathrm{NO}(\mathrm{g})+3 \mathrm{O}_{2}(\mathrm{~g})+2 \mathrm{H}_{2} \mathrm{O}(\mathrm{l}) \rightarrow 4 \mathrm{HNO}_{3}(\mathrm{l})$

ILs have ionic strengths which are of course much higher than for molecular liquids and higher than brine solutions as well. For ILs consisting of large organic cations and small inorganic anions, the base strength and the nucleophilicity of the anion is much higher than if the anion was solvated in water. ${ }^{[2]}$ Normally, $\mathrm{NO}$ is kinetically inert toward many common reactants but ILS provide a condensed medium containing strong nucleophiles. The absence of a full hydration shell decreases the activation barrier for nucleophilic attack. Based on the experimental evidence given here a mechanism for the oxidation reaction of NO in IL is suggested.

The oxidation of NO is reported in the literature to have the same rate law (2) in gas phase and in aqueous solution despite the total reactions being different. ${ }^{[28,29]}$ In this work a second order dependence on $p(\mathrm{NO})$ over the IL film was also found (see Fig. 7), and we expect the same rate law is relevant for the ratedetermining step in this IL solution.

$$
-\frac{d[\mathrm{NO}]}{d t}=k[\mathrm{NO}]^{2}\left[\mathrm{O}_{2}\right]
$$

Gas phase:

$2 \mathrm{NO}(\mathrm{g})+\mathrm{O}_{2}(\mathrm{~g}) \rightarrow 2 \mathrm{NO}_{2}(\mathrm{~g})$

Aqueous solution:

$4 \mathrm{NO}(\mathrm{g})+\mathrm{O}_{2}(\mathrm{~g})+2 \mathrm{H}_{2} \mathrm{O}(\mathrm{l}) \rightarrow 4 \mathrm{H}^{+}(\mathrm{aq})+4 \mathrm{NO}_{2}{ }^{-}(\mathrm{aq})$

In ILs an adduct can form between the IL anion and the NO molecule capturing and activating the NO for further reactions, 
since the anion is a powerful base and nucleophile. In the case of a nitrate IL the attack on NO can involve oxidation of the NO nitrogen which is thermodynamically favored. The product has one negative charge and is likely to be caught in the IL phase and to participate in further reactions. The initiation step in the condensed IL phase is thus proposed to be:

$\mathrm{NO}(\mathrm{g})+\mathrm{NO}_{3}{ }^{-}(\mathrm{IL}) \rightarrow \mathrm{N}_{2} \mathrm{O}_{4}{ }^{-}(\mathrm{IL})$

The unstable adduct $\mathrm{N}_{2} \mathrm{O}_{4}{ }^{-}$is then suggested to decompose to two species with the intermediate oxidation states of +III and +IV (6). Reactions (5) and (6) are analogous to the reaction between $\mathrm{NO}$ and $\mathrm{HNO}_{3}$ in the atmosphere or on surfaces. ${ }^{[30-33] \text {, }}$

$\mathrm{N}_{2} \mathrm{O}_{4}^{-}(\mathrm{IL}) \rightarrow \mathrm{NO}_{2}(\mathrm{IL})+\mathrm{NO}_{2}^{-}(\mathrm{IL})$

It was shown (see Fig. 5) that $\mathrm{NO}_{2}$ dimerizes to $\mathrm{N}_{2} \mathrm{O}_{4}$ in the IL when insufficient water is present (7).

$2 \mathrm{NO}_{2}(\mathrm{IL}) \rightarrow \mathrm{N}_{2} \mathrm{O}_{4}(\mathrm{IL})$

We expect $\mathrm{N}_{2} \mathrm{O}_{4}$ to be able to disproportionate to ions in an ionic media (8). This corresponds to the anhydrous form of the known disproportionation reaction occurring on surfaces. ${ }^{[34]}$

$\mathrm{N}_{2} \mathrm{O}_{4}(\mathrm{IL}) \rightarrow \mathrm{NO}_{2}^{+}(\mathrm{IL})+\mathrm{NO}_{2}^{-}(\mathrm{IL})$

Two nitrite anions from (6) or (8) could hypothetically be oxidized by $\mathrm{O}_{2}$ in one step (9):

$2 \mathrm{NO}_{2}^{-}(\mathrm{IL})+\mathrm{O}_{2}(\mathrm{~g}) \rightarrow 2 \mathrm{NO}_{3}^{-}(\mathrm{IL})$

However, reaction (9) is probably not very favored even in an IL phase since two anionic species have to be close together in order to allow reaction with one $\mathrm{O}_{2}$ molecule. Under dry conditions, the final products after complete oxidation are the ionic species $\mathrm{NO}_{2}{ }^{+}$and $\mathrm{NO}_{3}{ }^{-}$, as in the solid state of $\mathrm{N}_{2} \mathrm{O}_{5}$.

In the majority of the experiments enough water was present allowing reactions (10)-(12) to take place and several of the intermediates are observed in Fig. 5.

$\mathrm{N}_{2} \mathrm{O}_{4}(\mathrm{IL})+\mathrm{H}_{2} \mathrm{O}(\mathrm{IL}) \rightarrow \mathrm{HNO}_{3}(\mathrm{IL})+\mathrm{HNO}_{2}(\mathrm{IL})$

$\mathrm{HNO}_{2}(\mathrm{IL}) \rightarrow \mathrm{NO}_{2}^{-}(\mathrm{IL})+\mathrm{H}^{+}(\mathrm{IL})$

$\mathrm{HNO}_{2}(\mathrm{IL})+\mathrm{NO}_{2}^{-}(\mathrm{IL}) \rightarrow \mathrm{HN}_{2} \mathrm{O}_{4}^{-}{ }^{-}(\mathrm{IL})$

The protons generated will prefer $\mathrm{NO}_{2}^{-}$over $\mathrm{NO}_{3}{ }^{-}$since nitrite is the stronger base. The dimeric species $\mathrm{HN}_{2} \mathrm{O}_{4}{ }^{-}(\mathrm{IL})$ and the nitrous acid dimer have a strong hydrogen bond keeping the two nitrogen(III) species close together. The nitrogen(III) species have thus been activated for oxidation by dioxygen in one step. The product is the analogous nitric acid-nitrate dimer:

$\mathrm{HN}_{2} \mathrm{O}_{4}^{-}(\mathrm{IL})+\mathrm{O}_{2}(\mathrm{IL}) \rightarrow \mathrm{HN}_{2} \mathrm{O}_{6}{ }^{-}(\mathrm{IL})$

This corresponds well to the observed $\sim 1: 1$ molar ratio between $\mathrm{HNO}_{3}$ and IL after gas saturation. When the IL is saturated with $\mathrm{HNO}_{3}$ there are just enough protons to allow every proton to form a strong hydrogen bond between two nitrate anions. No free basic nitrate anions are then available for nucleophilic attack on $\mathrm{NO}$, only allowing $\mathrm{HNO}_{3}$ to accumulate very slowly in the IL after this point (see Fig. 7). The nitrate-nitric acid dimer is clearly observable in the IR spectrum and is the final product until the nitric acid is desorbed by raising the temperature:

$\mathrm{HN}_{2} \mathrm{O}_{6}{ }^{-}(\mathrm{IL}) \rightarrow \mathrm{HNO}_{3}(\mathrm{~g})+\mathrm{NO}_{3}{ }^{-}(\mathrm{IL})$

An analogue to reaction (13) has previously been suggested to explain why the rate of oxidation of $\mathrm{NO}_{x}$ by dioxygen was observed to be several orders of magnitude faster just around 0 ${ }^{\circ} \mathrm{C}$ in water droplets. ${ }^{[35,36]}$ The freeze-concentration effect leads the $\mathrm{HNO}_{2}$ concentration to increase drastically in the remaining liquid phase by a factor of 240-11000. ${ }^{[37]}$ The formed $\mathrm{HNO}_{2}$ dimers are activated towards oxidation by $\mathrm{O}_{2}$ :
$(\mathrm{HONO})_{2}(\mathrm{aq})+\mathrm{O}_{2}(\mathrm{aq}) \rightarrow 2 \mathrm{HNO}_{3}(\mathrm{aq})$

In the IL phase a single proton assures that nitrogen(III) species are held together, activating them towards oxidation by $\mathrm{O}_{2}$ in an analogous manner.

Reaction (13) is suggested to be the rate-determining step after a series of pre-equilibria: (5)-(7) and (10)-(12). This is in accordance with the overall reaction order of two with respect to NO. The complete reaction pathway consisting of reactions (5)(7) and (10)-(14) is shown in the catalytic cycle in Scheme 3, having the stoichiometry of the total reaction in reaction (1). The individual reactions with coefficients are listed in Table S1 (Supporting Information). The appearance of the cycle is complicated by the demands of stoichiometry and the suggestion of elementary reactions but can be considered in a simple way as nitrate oxidizing $\mathrm{NO}$ to $\mathrm{HNO}_{3}$ and thereby being reduced itself to nitrite. $\mathrm{O}_{2}$ then reoxidizes nitrite to nitrate regenerating the catalyst.

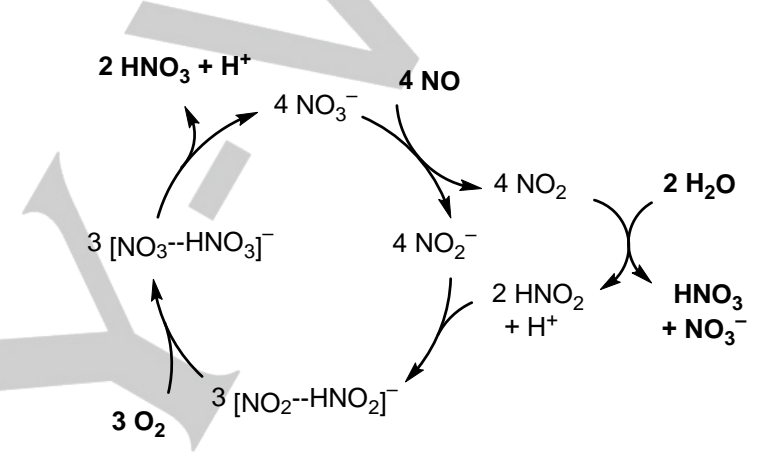

Total reaction:

$4 \mathrm{NO}+3 \mathrm{O}_{2}+2 \mathrm{H}_{2} \mathrm{O} \longrightarrow 4 \mathrm{HNO}_{3}$

Scheme 3: Stoichiometric reaction cycle for the oxidation of $\mathrm{NO}$ to $\mathrm{HNO}_{3}$ catalyzed at RT by nitrate based ILs (reactants and products are in bold).

It should be noted that the chemistry is similar to what would be expected in aqueous solution. The difference observed is due to an enhanced activity of the nitrate anions in IL solution since they are not solvated by water molecules. Also the interaction between typically large cations of ILS with the anions is significantly weaker compared to the interaction by the typically smaller inorganic cations (e.g. $\mathrm{Na}^{+}$) with the anions. ${ }^{[38]}$ Furthermore, the generation of dimeric units of $\mathrm{N}(\mathrm{III})$ species coupled by hydrogen bonding has a favorable impact on the rate of oxidation with $\mathrm{O}_{2}$, which is the rate determining step.

In ILs with other anions than nitrate, a different initiation reaction for the catalytic cycle must take place: Acetate is not an oxidant but is still a good nucleophile that can capture NO in the condensed phase. The reaction mechanism for this initiation is not clear, but it is possible that a small percentage of $\mathrm{NO}_{2}$ present in the gas can disproportionate and start the process or that $\mathrm{O}_{2}$ could participate in radical reactions for the initiation reaction. After a while, nitrate accumulates and the reaction proceeds like in nitrate based ILs. The ILs with anions which are stronger bases than nitrate will be converted to the 
corresponding nitrate IL after one cycle. Acetate is a very powerful Lewis and Brønsted base in a pure $\mathrm{IL}^{[24]}$ and FTIR measurements performed on [BMIM] $\left[\mathrm{CH}_{3} \mathrm{COO}\right.$ (Fig. 2) and [Ch] $\left[\mathrm{CH}_{3} \mathrm{COO}\right]$ (Fig. S4, Supporting Information) show that IR features assignable to acetate at $1550 \mathrm{~cm}^{-1}$ decrease very quickly as nitrate and acetic acid bands increases. As NO is absorbed and oxidized, nitric acid is formed but the protons are removed immediately by acetate. Judged from the decreasing intensity of the band at $1715 \mathrm{~cm}^{-1}$ with time, the acetic acid is slowly removed from the liquid even at RT. In the bulk experiments with [BMIM] $\left[\mathrm{CH}_{3} \mathrm{COO}\right]$, acetic acid was absent according to NMR analysis after one absorption-desorption cycle. When starting from a more basic anion than nitrate, it is suggested that the generated, unprotonated nitrate anion is involved in the further absorption and oxidation of NO. Furthermore, as acids accumulate in the IL, the nitric acid will be retained more strongly than the other acids due to its formation of a high-boiling azeotrope with water having a pattern of strong hydrogen bonds.

\section{Conclusions}

Nitrate is a catalyst for the oxidation of $\mathrm{NO}$ by $\mathrm{O}_{2}$ to nitric acid. Nitrate is reduced to nitrite by $\mathrm{NO}$ and is reoxidized by $\mathrm{O}_{2}$ restoring the catalyst. Aqueous nitrate solutions have modest activity towards this reaction. By using a nitrate based ionic liquid, the catalyst is an integral part of the reaction medium, the reaction is at least three times faster than in aqueous solution with comparable nitrate concentration, and, most importantly, the reaction can be run in a continuous flow without the reaction media being lost by evaporation. Under exactly the same conditions the IL does not absorb either $\mathrm{CO}_{2}$ or $\mathrm{SO}_{2}$ to any measurable extent.

Interconversion between the different nitrogen species in the condensed IL phase is likely dynamic and fast and the concentrations are the equilibrium values. The most reactive species towards oxidation by dioxygen is expected to be a nitrite-nitrous acid adduct or a nitrous acid dimer. Both are poised to deliver four electrons to a dioxygen molecule and make the corresponding dimeric nitrogen $(V)$ species without oxygen radical intermediates. The hydrogen bonds formed serve to retain the nitrogen species in the IL phase removing them from the gas phase. This method is therefore a tool to absorb exhaust $\mathrm{NO}_{\mathrm{x}}$ species from off gasses and storing them. The absorption ability can be restored in a desorption step at higher temperatures. No deterioration of the absorption properties of the IL is observed even after many absorption-desorption cycles. After saturation all nitrate ions participate in strong hydrogen bonds and the molar ratio between $\mathrm{NO}_{3}{ }^{-}$and $\mathrm{HNO}_{3}$ is $\sim 1: 1$. Thus, the resulting mixture after saturation with $\mathrm{HNO}_{3}$ can be formulated as a new IL: [BMIM] $\left[\mathrm{NO}_{3} \cdot \cdot \mathrm{HNO}_{3}\right]$. The product after desorption is a concentrated $\mathrm{HNO}_{3}$ stream that can be condensed with water as nitric acid of commercial grade.

The cation of the IL has no apparent influence on the absorption reaction and in most cases the anion is converted to nitrate after one absorption-desorption cycle. Thus, ILs like the non-toxic cholinium chloride used as a vitamin additive for livestock is expected to be just as effective as traditional imidazolium-based $\mathrm{IL}$ and can be obtained at a much lower cost.

In order to overcome the mass-transfer limitations for the interaction of bulk ILs with the gas phase, solid absorbers with ILs impregnated on porous silica or other porous supports can be made. The resulting SILP materials ${ }^{[9,27]}$ are very promising for the application as reversible $\mathrm{NO}_{x}$ absorbers in end-of-pipe installations of industrial units emitting $\mathrm{NO}_{x}$ like, e.g. power plants, ships and cement factories. Investigations with such SILP absorbers are ongoing.

\section{Experimental Section}

[BMIM][NO ${ }_{3}$ ] (>98\%, loLiTec), [BMIM][CH $\mathrm{CH}_{3} \mathrm{COO}$ ( $>98 \%$, Sigma-Aldrich) [BMIM]Cl (95\%, Sigma-Aldrich), [BMMIM][NO $\left.{ }_{3}\right] \quad(>98 \%, \quad$ loLiTec), $[\mathrm{Ch}]\left[\mathrm{CH}_{3} \mathrm{COO}\right]$ (95\%, Sigma-Aldrich) and $[\mathrm{EMIM}]\left[\mathrm{CF}_{3} \mathrm{SO}_{3}\right](>99 \%$, loLiTec) were obtained from commercial sources and used as received. [Ch] $\left[\mathrm{NO}_{3}\right]$ was produced in-situ by exposing $[\mathrm{Ch}]\left[\mathrm{CH}_{3} \mathrm{COO}\right]$ to a gas mixture of $\mathrm{NO} / \mathrm{O}_{2} /$ water in nitrogen followed by heating to $120^{\circ} \mathrm{C}$ in a flow of nitrogen

The gas streams were mixed from $10 \% \mathrm{v} / \mathrm{v} \mathrm{NO}$ in $\mathrm{N}_{2}, \mathrm{~N}_{2}, \mathrm{CO}_{2}, 2 \% \mathrm{v} / \mathrm{v}$ $\mathrm{SO}_{2}$ in $\mathrm{N}_{2}$ and air. All gasses were delivered by AGA. The gas flow was controlled by mass flow controllers (Bronkhorst). To obtain a wet gas the air or $\mathrm{N}_{2}$ stream was led through water or $\mathrm{D}_{2} \mathrm{O}(99.9 \%$, Sigma-Aldrich) in a bubble flask fitted with a glass frit and joined with the NO gas just before the reactor. $\mathrm{NO}$ and $\mathrm{O}_{2}$ was led through stainless steel tubing (Swagelok) close to the reactor chamber in order to minimize autoxidation of $\mathrm{NO}$ in the gas phase which is facilitated by sunlight. $\mathrm{NO}_{2}$ was generated by treating copper metal with $\mathrm{HNO}_{3}$ (65\%, Sigma-Aldrich). Prior to subjecting the IL sample to the gas, the gas was dried through a column with activated molecular sieves (4 $\AA$ ). ATR-FTIR experiments were performed on a Nicolet iS5 spectrometer equipped with a thermoregulated (up to $300^{\circ} \mathrm{C}$ ) Specac Golden Gate High Temperature diamond ATR cell. This was fitted with an add-on cap, allowing the controlled gas mixture to flow over the diamond of the instrument at atmospheric pressure (Fig. S7, Supporting Information). The experiments were performed with 1-6.5 \% v/v NO, 8-20 \% v/v O, $1-1.5 \% \mathrm{v} / \mathrm{v}$ water at $50 \mathrm{~mL} / \mathrm{min}$. The IL was applied as a thin film in the center of the diamond before securing the add-on cap. For the IL screening experiments, the gas exchange was performed with a valve outside the add-on cap and a reproducible delay before the reaction was present. The time resolved experiments with $[\mathrm{BMIM}]\left[\mathrm{NO}_{3}\right]$ were performed with the atmosphere in the cap being equilibrated before quickly adding the cap over the IL film on the ATR diamond. The reaction and absorption was followed in real time by recording spectra continuously. For each spectrum, 4-16 scans with $4 \mathrm{~cm}^{-1}$ resolution (approximately 5-20 s measuring time) were performed. The spectra were background and ATR corrected in OMNIC 8.2 assuming a refractive index of 1.5 and a reflectance angle of $90^{\circ}$. Gaussian deconvolution using PeakFit ${ }^{[39]}$ was performed individually in the area of the 948 and $1660 \mathrm{~cm}^{-1}$ peaks of $\mathrm{HNO}_{3}$. To allow for batch deconvolution, a method was developed for Gnuplot $4.1 .^{34}$ Further details on the deconvolution method can be found in literature. ${ }^{[23]}$ The shown full spectra in Figure 1-6 were all obtained at RT. Spectra (not shown) obtained at temperatures up to $60{ }^{\circ} \mathrm{C}$ were the basis for the results shown in Figure 7, bottom.

The bulk experiments were performed in 5 series in a $15 \mathrm{~mL}$ custom made cylindrical Schlenk flask fitted with a tube (with or without a glass frit) reaching almost to the bottom and valves both on the inlet and outlet. 
Enough liquid is added to cover the opening of the insert so the gas is passing through the liquid. After closing the valves, the entire flask can be disconnected from the gas line and weighed.

For series 1 and 2, [BMIM] [CH $\mathrm{CH}_{3} \mathrm{COO}$ ( $1 \mathrm{~mL}$ ) were used. For series 3 and 5, [BMIM] [NO $\mathrm{NO}_{3}$ ( $1 \mathrm{~mL}$ and $0.9 \mathrm{~mL}$, respectively) were used. For series 4 , $\mathrm{NaNO}_{3}(2 \mathrm{~mL}, 6 \mathrm{M})$ in degassed water were used. The gasses were pure $10 \% \mathrm{v} / \mathrm{v} \mathrm{NO}$ at $10 \mathrm{~mL} / \mathrm{min}$ for series 1 and 2; $5 \% \mathrm{v} / \mathrm{v} \mathrm{NO}, 10 \% \mathrm{v} / \mathrm{v} \mathrm{O}$ and $\sim 1 \% \mathrm{v} / \mathrm{v}$ water at $30 \mathrm{~mL} / \mathrm{min}$ for series 3; and $5 \% \mathrm{v} / \mathrm{v} \mathrm{NO}, 10 \% \mathrm{v} / \mathrm{v}$ $\mathrm{O}_{2}$ and $\sim 1 \% \mathrm{v} / \mathrm{v}$ water at $10 \mathrm{~mL} / \mathrm{min}$ for series 4 and 5 . All five series were followed gravimetrically by weighing several times. In series 1 and 2 the reaction vial was submerged in an oil bath at $100{ }^{\circ} \mathrm{C}$ while under the gas flow for several days to obtain steady state. Then the oil bath was removed and the flask cooled down to RT. Still under flow, a new steady state was obtained at room temperature after several days. Series 3 were performed at RT and followed by weighing multiple times. Series 4 and 5 consists of several individual experiments at RT which were stopped after 2, 4, 6, 8 and 10 hours, respectively, by adding a total of 50 $\mathrm{mL}$ degassed water in several portions and transferring the resulting solution to an Erlenmeyer flask. Thymol blue was added as acid/base indicator and the amount of acidic protons were determined by titration with $\mathrm{NaOH}(0.100 \mathrm{M})$. For series 4 and 5 the experiments were reproduced with an open end glass tube. This had little influence for the experiments with IL but problem with clogging of the frit with $\mathrm{NaNO}_{3}$ in the aqueous solution bulk experiments were avoided giving more reproducible results.

NMR spectra were recorded at RT on a Bruker $300 \mathrm{MHz}$ NMR instrument of $\mathrm{CDCl}_{3}$ solutions/inhomogeneous mixtures of pure [BMIM][ $\left.\mathrm{NO}_{3}\right]$ and [BMIM] $\left[\mathrm{CH}_{3} \mathrm{COO}\right]$ as well as of the ILs after saturation with $\mathrm{NO}$ gas in the bulk at RT as described above under series 3 and subsequent desorption without flow at $110^{\circ} \mathrm{C}$ for $3 \mathrm{~h}$. [BMIM] $\left[\mathrm{NO}_{3}\right] \delta^{1} \mathrm{H} / \mathrm{ppm}\left(\mathrm{CDCl}_{3}\right): 0.86(3 \mathrm{H}$, butyl), $1.28(2 \mathrm{H}$, butyl), $1.78(2 \mathrm{H}$, butyl), $3.93(3 \mathrm{H}$, methyl), $4.16(2 \mathrm{H}$, butyl), $7.42(1 \mathrm{H}, \mathrm{C} 5), 7.48(1 \mathrm{H}, \mathrm{C} 4)$ and $9.62(1 \mathrm{H}, \mathrm{C} 2) ; \delta{ }^{13} \mathrm{C} / \mathrm{ppm}$ $\left(\mathrm{CDCl}_{3}\right): 13.5,19.5,32.2,36.4,49.9,122.5,124.0$ and 137.7 (impurities: 54.7, $104.6 \mathrm{ppm})$. [BMIM] $\left[\mathrm{CH}_{3} \mathrm{COO}\right]$ after reaction $\delta{ }^{1} \mathrm{H} / \mathrm{ppm}\left(\mathrm{CDCl}_{3}\right)$ : 0.92 (3H, butyl), 1.33 (2H, butyl), $1.84(2 \mathrm{H}$, butyl), $3.96(3 \mathrm{H}$, methyl), 4.20 (2H, butyl), $7.37(1 \mathrm{H}, \mathrm{C} 5), 7.41(1 \mathrm{H}, \mathrm{C} 4)$ and $9.42(1 \mathrm{H}, \mathrm{C} 2), 13.52(0.5 \mathrm{H}$, $\left.\mathrm{HNO}_{3}\right) ; \delta{ }^{13} \mathrm{C} / \mathrm{ppm}\left(\mathrm{CDCl}_{3}\right): 13.5,19.6,32.2,36.5,50.1,122.5,123.9$, 137.5 (impurity: 54.7).

TGA were performed on a Mettler Toledo TGA/DSC 1 STARe system in a flow of nitrogen of $70 \mathrm{~mL} / \mathrm{min}$. Samples were heated from RT to $600^{\circ} \mathrm{C}$ at $10^{\circ} \mathrm{C} / \mathrm{min}$.

Determination of water contents in the ILs were performed by Karl Fischer titration on a Metrohm 888 Titrando by analyzing 3 samples of $0.1 \mathrm{~mL}$.

\section{Acknowledgements}

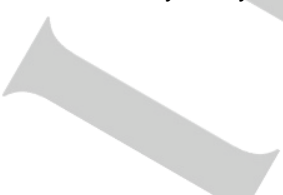

This work is financially supported by Energinet.dk through the PSO project 10521 and Copenhagen Cleantech Cluster (GAP project no. 91050-ko). S.M thanks the Danish Independent Research Council DFF (project no. 09-070250). FP7 COST Action CM1306 EXIL is acknowledged for financial support for dissemination. Dr. Johannes Due Hansen, Thorey Grettarsdottir and Anita Godiksen, Centre for Catalysis and Sustainable Chemistry, DTU Chemistry, Technical University of Denmark are acknowledged for performing preliminary investigations. LAB
S.A, France and DONG Energy, Denmark are also thanked for financial support and valuable discussions.

Keywords: Ionic liquids $\bullet \mathrm{NO}_{\mathrm{x}} \bullet$ in situ ATR-FTIR $\bullet$ gas absorption $\bullet$ nitric acid

[1] Health Aspects of Air Pollution with Particulate Matter, Ozone and Nitrogen Dioxide : Report on a WHO Working Group, World Health Organization. Regional Office For Europe, 2003.

[2] N. Meine, F. Benedito, R. Rinaldi, Green Chem. 2010, 12, 17111714.

[3] C. P. Fredlake, J. M. Crosthwaite, D. G. Hert, S. N. V. K. Aki, J. F. Brennecke, J. Chem. Eng. Data 2004, 49, 954-964.

[4] A. Noda, M. A. B. H. Susan, K. Kudo, S. Mitsushima, K. Hayamizu, M. Watanabe, J. Phys. Chem. B 2003, 107, 4024-4033.

[5] H. Tokuda, K. Hayamizu, K. Ishii, M. A. B. H. Susan, M. Watanabe, J. Phys. Chem. B 2004, 108, 16593-16600.

[6] J. Huang, A. Riisager, P. Wasserscheid, R. Fehrmann, Chem. Commun. 2006, 38, 4027-4029.

[7] C. Wang, G. Cui, X. Luo, Y. Xu, H. Li, S. Dai, J. Am. Chem. Soc. 2011, 133, 11916-11919.

[8] J. F. Brennecke, B. E. Gurkan, J. Phys. Chem. Lett. 2010, 1, 34593464.

[9] P. Thomassen, A. Riisager, A. J. Kunov-Kruse, S. Mossin, H Kolding, S. Kegnæs, R. Fehrmann, ECS Trans. 2012, 50, 433-442.

[10] Z. Lei, C. Dai, B. Chen, Chem. Rev. 2014, 114, 1289-1326.
[11] R. W. Berg, P. Harris, A. Riisager, R. Fehrmann, J. Phys. Chem. A 2013, 117, 11364-11373.

[12] L. Cammarata, S. G. Kazarian, P. A. Salter, T. Welton, Phys. Chem Chem. Phys. 2001, 3, 5192-5200.

[13] L. J. Murphy, A. M. McPherson, K. N. Robertson, J. A. C. Clyburne, Chem. Commun. 2012, 48, 1227-1229.

[14] A. Riisager, A. J. Kunov-Kruse, S. Mossin, R. Fehrmann, Absorption and Oxidation of NO in Ionic Liquids, 2013, WO2013079597.

[15] F. Mélen, M. Herman, J. Phys. Chem. Ref. Data 1992.

[16] D. C. Harris, M. D. Bertolucci, Symmetry and Spectroscopy, Oxford University Press, 1978.

[17] K. Noack, P. S. Schulz, N. Paape, J. Kiefer, P. Wasserscheid, A. Leipertz, Phys. Chem. Chem. Phys. 2010, 12, 14153-14161.

[18] M. J. Frisch, G. W. Trucks, H. B. Schlegel, G. E. Scuseria, M. A. Robb, J. R. Cheeseman, G. Scalmani, V. Barone, B. Mennucci, G. A. Petersson, et al., 2009

[19] H.-P. Steinrück, P. Wasserscheid, Catal. Letters 2015, 145, 380397.

[20] M. Thiemann, E. Scheibler, K. W. Wiegand, Ullmann's Encycl. Ind. Chem. Vol. 24 2012, 177-223.

[21] H. A. Duong, T. N. Tekavec, A. M. Arif, J. Louie, Chem. Commun. 2004, 2, 112-113.

[22] R. N. Wiener, E. R. Nixon, J. Chem. Phys. 1957, 26, 906-908.

[23] A. J. Kunov-Kruse, A. Riisager, S. Saravanamurugan, R. W. Berg, S. B. Kristensen, R. Fehrmann, Green Chem. 2013, 15, 2843-2848.

[24] Z. Guo, B.-M. Lue, K. Thomasen, A. S. Meyer, X. Xu, Green Chem. 2007, 9, 1362-1373. 
J. L. Anthony, J. L. Anderson, E. J. Maginn, J. F. Brennecke, J. Phys. Chem. B 2005, 109, 6366-6374.

[26] H. Tsukahara, T. Ishida, Y. Todoroki, M. Hiraoka, M. Mayumi, Free Radic. Res. 2003, 37, 171-177.

[27] H. Kolding, P. Thomassen, S. Mossin, S. Kegnæs, A. Riisager, J. Rogez, G. Mikaelian, R. Fehrmann, ECS Trans. 2014, 64, 97-108.

[28] P. C. Ford, D. A. Wink, D. M. Stanbury, FEBS Lett. 1993, 326, 1-3. S. Goldstein, G. Czapski, J. Am. Chem. Soc. 1995, 117, 1207812084.

[30] B. J. Finlayson-Pitts, N. A. Saliba, L. M. Wingen, W. S. Barney, M. Mochida, H. Yang, Rep. Calif. Air Ressources Board Calif. Environ. Prot. Agency 2001, 1-166.

[31]
M. Mochida, B. J. Finlayson-Pitts, 2000, 104, 9705-9711.

J. Kleffmann, T. Benter, P. Wiesen, J. Phys. Chem. A 2004, 108,
5793-5799.

[33] R. Svensson, E. Ljungström, Int. J. Chem. Kinet. 1988, 20, 857-866.

[34] T. Kinugawa, S. Enami, A. Yabushita, M. Kawasaki, M. R. Hoffmann, A. J. Colussi, Phys. Chem. Chem. Phys. 2011, 13, 5144-9.

[35] D. E. Damschen, L. R. Martin, Atmos. Environ. 1983, 17, 20052011.

[36] P. K. Mudgal, S. P. Bansal, K. S. Gupta, Atmos. Environ. 2007, 41, 4097-4105.

[37] N. Takenaka, A. Ueda, T. Daimon, H. Bandow, T. Dohmaru, Y. Maeda, J. Phys. Chem. 1996, 100, 13874-13884.

[38] Q. Yang, H. Xing, Z. Bao, B. Su, Z. Zhang, Y. Yang, S. Dai, Q. Ren, J. Phys. Chem. B 2014, 118, 3682-3688.

[39] PeakFIT v. 4.11, Systat Software Inc, 2009. 
Entry for the Table of Contents (Please choose one layout)

Layout 1:

\section{FULL PAPER}

The answer is NO! A new vision for removing NO from exhaust gases is presented. Nitrate-based ionic liquids catalyze the fast oxidation of NO by $\mathrm{O}_{2}$ to nitric acid, which is accumulated in the non-volatile ionic liquid to $1: 1$ at room temperature. The reaction is followed in-situ in a thin film by ATRFTIR. A mechanism for the catalytic reaction is suggested revealing the importance of the anion for the reactivity of the ionic liquid.

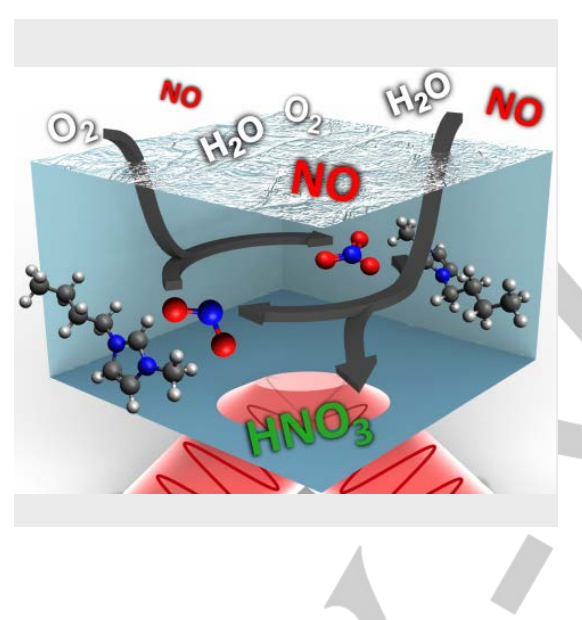

Andreas J. Kunov-Kruse ${ }^{[a]}$, Peter L. Thomassen $^{[a]}$, Anders Riisager ${ }^{[a]}$, Susanne Mossin ${ }^{\star[a]}$, Rasmus Fehrmann ${ }^{\star[a]}$

Page No. - Page No.

Absorption and oxidation of nitrogen oxide in ionic liquids

Layout 2:

\section{FULL PAPER}

((Insert TOC Graphic here; max. width: $11.5 \mathrm{~cm}$; max. height: $2.5 \mathrm{~cm}$ ))
Author(s), Corresponding Author(s)*

Page No. - Page No.

Title 